\title{
Developing Student's Activity with Wisanggeni Puppet Context to Enhance Students' Understanding of Addition and Substraction Thousands Number
}

\author{
Bagas Widyo Arbowo, Aidha Aprilia P L, Fifin Aisyah, and Farida Nursyahidah \\ Faculty of Mathematics and Natural Science Education and Information Technology, Universitas PGRI Semarang, \\ 50125, Indonesia \\ faridanursyahidah@upgris.ac.id
}

\begin{abstract}
This research aims to develop Student Activity Sheet to enhance understanding addition and subtraction thousand numbers for students in the fourth grade with context Wisanggeni Puppet and to determine the feasibility of Student Activity Sheet based on the assessment of subject-matter expert and design expert, as well as student assessment on individual test. It was a developmental research or Research and Development (R\&D), adapted from ADDIE development model. There were 5 ADDIE phases namely: 1) Analysis, 2) Design, 3) Development, 4) Implementation, and 5) Evaluation. The development stage that is analyzing core competence, basic competence, indicator, literature study, designing teaching materials in accordance with students needs, making product, then product validation by field trial and data that has been obtained from field trials evaluated. In this Student Activity Sheet with Wisanggeni Puppet Context students are also required to think critically and creatively through the working steps are ordered in Student Activity Sheet with Wisanggeni Puppet Context and questions relating to Wisanggeni Puppet stories that appear to accompany the material concept of addition and subtraction of numbers in the thousands. Validation was carried out by two subject-matter experts and two design experts. The Student Activity Sheet developed was tested in one phase namely individual test with the subject of 3 students with different abilities. In the development of Student Activity Sheet that the researcher did, the ADDIE stages were carried out until the development phase. The result of this research are score of validation result and student activity sheet that valid criteria.
\end{abstract}

Keywords- Student Activity Sheet, Wisanggeni puppet, addition, subtraction, thousands number, ADDIE.

\section{INTRODUCTION}

Mathematics as a basic science plays a very important role in the development of science and technology [1]. The importance of mathematics is also recognized by Cockroft [2] which states it would be very difficult for a person to live on this part of the world in the 20th century without the slightest use of mathematics. Mathematics lessons at school play a role in training students to think logically, critically, and practically and be positive and creative spirited [3]. It shows the importance of learning mathematics. One of the important scopes of mathematics to study is algebra [4]. However, according to [5] [6] number operation is still one of the difficult material, especially for the material of addition and subtraction of thousand numbers in the fourth grade of elementary school.

The difficulty of students is when they are encouraged to develop their own meaningful prior computational strategies to algorithms being introduced, they demonstrate their mathematical understanding rooted in number sense and place value [7] [8] [9]. Selter [10] also noted that it is frequently beneficial to allow students to derive their own algorithms because different problems are better suited to work with certain numbers. This point of view is supported by Carrol [11] who reported that elementary aged students preferred adding from left to right. When doing so, the children developed both a partial sums strategy where students would add according to the addends place value and a cumulative sums strategy where the students would calculate a running sum when adding portions of a decomposed second addend [7]. Similarly, Beishuizen [8] identified analogous left to right mental strategies for addition. Among the strategies were a split strategy where addends are added according to place values, and a jumping strategy where a collective sum is amassed.

Inability to recognize numbers often leads to the inability to deduce which of two numbers is the largest and to perceive low numbers that are larger than four [13] as anything else than a series of "ones" [14]. Students having these difficulties are often seen counting on their fingers. Processing numerical information also means being able to understand and realize how numbers are influenced by simple arithmetic operations for adding.

To create and escalate students' mastery of concept mathematics of addition and subtraction thousands number, teachers as an educator need to find a solution so that the students can understand the concepts in mathematics. One solution that can be considered is to develop teaching 
materials printed in the form of Student Activity Sheet. Student Activity Sheet is a way to assist and facilitate in the learning activities that will form an effective interaction between students and teachers and may enhance the activity of students in the improvement of learning achievement. As said by Prastowo [15], the teaching material of Student Activity Sheet is simpler than the module, but more complex than book. According to [15], Student Activity Sheet is a teaching material printed in the form of sheets of paper containing materials, summaries and instructions of the implementation of learning tasks that must be performed by learners which refers to the basic competencies that must be achieved. That is why the writer chose to develop Student Worksheet in conducting this research.

Therefore, in the Student Activity Sheet needs an effective contextual approach. According to [16] [sagita 12] one of the most effective approaches in mathematics learning is the Indonesian Realistic Mathematics Approach (PMRI). PMRI is a learning approach that leads to meaningful learning, in accordance with students' thinking ability and related to the daily life of students [9] [artawan 1]. The use of PMRI approach has been widely used as one of the efforts to improve the interest of students, the attitude and the results of the study ([17-21]). Some contexts in learning mathematics that can be used is traditional games ([22], [23], [18], [19]), certain society habit [20], and folktales, legends ([24], [25]). In this research, the context that can be applied in addition and subtraction material is one of local wisdom that is known as Wisanggeni Puppet. Because the Wisanggeni puppet's figure have a good character that is why it can be a role model for young people especially for early age [26]. In the learning process, the abstract mathematical concepts need to be transformed into real things in order to help the students to understand the concept.

This research aims to produce a Student Activity Sheet with context of Wisanggeni Puppet on the material addition and subtraction of the thousands number. The benefits of this development is to produce a student activity sheet product with the context of wayang wisanggeni to enhance understanding of addition and subtraction of thousands number.

\section{METHOD}

Research of developing Student Activity Sheet based on the assessment of subject-matter expert and design expert, as well as student assessment on individual test. It was a developmental research or Research and Development (R\&D), adapted from ADDIE development model. There were 5 ADDIE phases namely: 1) Analysis, 2) Design, 3) Development, 4) Implementation, and 5) Evaluation. The development stage that is analyzing core competence, basic competence, indicator, literature study, designing teaching materials in accordance with students needs, making product, then product validation by field trial and data that has been obtained from field trials evaluated. Validation was carried out by two subject-matter experts and two design experts. The Student Activity Sheet developed was tested in one phase namely individual test with the subject of 3 students with different abilities. In the development of Student Activity Sheet that the researcher did, the ADDIE stages were carried out until the development. The level of feasibility of SAS is measured using the criteria of the validity of teaching materials. It can be seen in Table 1 .

TABLE I. CRITERIA OF MATERIAL VALIDITY

\begin{tabular}{|c|l|l|l|}
\hline No. & Percentage (\%) & Criteria & \multicolumn{1}{|c|}{$\begin{array}{c}\text { Level of } \\
\text { Validity }\end{array}$} \\
\hline 1 & $85.01-100.00$ & $\begin{array}{l}\text { Very } \\
\text { valid }\end{array}$ & $\begin{array}{l}\text { Very valid or } \\
\text { usable but needs } \\
\text { to be revised }\end{array}$ \\
\hline 2 & $70.01-85.00$ & Valid & $\begin{array}{l}\text { Valid or usable } \\
\text { but need to be } \\
\text { revised }\end{array}$ \\
\hline 3 & $50.01-70.00$ & $\begin{array}{l}\text { Less } \\
\text { valid }\end{array}$ & $\begin{array}{l}\text { Less valid and } \\
\text { recommended } \\
\text { not to be used } \\
\text { because of large } \\
\text { revisions. }\end{array}$ \\
\hline 4 & $01.00-50.00$ & Invalid & $\begin{array}{l}\text { Invalid or cannot } \\
\text { be used. }\end{array}$ \\
\hline
\end{tabular}

\section{RESULTS AND DISCUSSION}

The developmental stages of the ADDIE model:

\section{A. Analyze}

The steps to be performed on the analyze phase were as follows:

\section{Curriculum Analysis}

This step was useful to know the curriculum used in schools, know the syllabus and competencies that will be achieved as well as what the existing materials in mathematics that can be used as resource materials for the making of math Student Worksheet in the form of Student Activity Sheet with Wisanggeni Puppet Context.

\section{Validating Performance Gaps}

The purpose of validating the performance gap was to produce a statement relating to a problem, find out the cause and finally find the solutions from the gaps or problems that arise. To find out the problems that occurred, the researcher conducted observations addressed to teachers on learners and school environment.

\section{Determining Goals}


After finding the problem and analyze it, then the next step was to set goals. These goals were expected to overcome the existing problems in the learning process. This was conducted by giving the right solution to the gap and desired expectations.

\section{Analysis of Learners}

Analysis of learners was performed with the aim to identify the initial ability, experience, likes and learning motivation. To be able to know this problem, the researcher conducted interviews addressed to learners.

\section{Available Resources}

There are four types of resources that should be known namely the content resources, technology resources, teaching facilities and human resources. All types of these resources must be known in order to complete the ADDIE process. To be able to know this problem, the researcher conducted interviews to the school regarding the resources available in schools.

\section{Work Plan}

The work plan was needed in a development. A work plan in question was to set up the stage of manufacture of products that would be produced by the researcher until the final develop phase.

\section{B. Design}

At this phase, all the things that needed would be made in accordance with what was on the analyze phase. All begin to be realized to produce a product that could be used in learning activities. The products that would be produced by the researcher was in the form of Student Worksheet in the form of Student Activity Sheet with Wisanggeni Puppet Context and used as teaching material during the learning process.

This is the one of Student Activity Sheet's design:

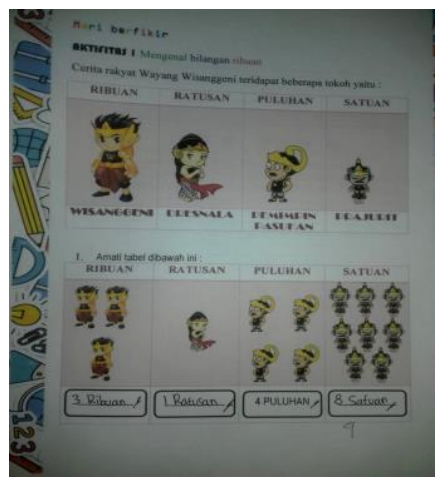

Figure 1. The design of Students Activity Sheet

\section{Develop}

After the steps in the design phase were carried out, the next step was to develop. The steps to be performed in this phase was to make the Student Worksheet in the form of Student Activity Sheet with Wisanggeni Puppet Context, validate the Student Activity Sheet to four experts, namely two subject matter experts, one media expert and one design expert. Individual and small group tests were also conducted in this phase.

Based on the results of questionnaires given to students, found that Student Activity Sheet with Wisanggeni Puppet Context interesting to be implemented on a material addition and subtraction of numbers thousands cause can improve motivation, interests, and student participation in learning. In this Student Activity Sheet with Wisanggeni Puppet Context students are also required to think critically and creatively through the working steps are ordered in Student Activity Sheet with Wisanggeni Puppet Context and questions relating to Wisanggeni Puppet stories that appear to accompany the material concept of addition and subtraction of numbers in the thousands.

Here is an example of the students' answers on Student Activity Sheet with Wisanggeni Puppet Context:

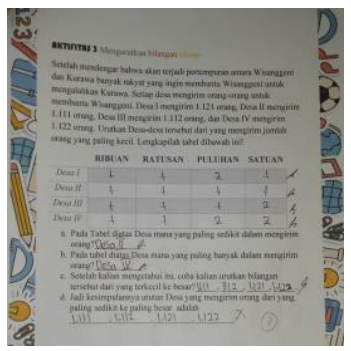

Figure 2: an example of students unswer on Activity 3

The validity of Student Activity Sheet with Wisanggeni Puppet context on the material is seen from the results of the addition and subtraction thousands numbers validation of material, design and media. From the results of material validation with a percentage of $88,7 \%$ was obtained, so the product was valid. From the results of design validation, with a product percentage of $73 \%$ was obtained, so the product was very valid. From the results of media validation, with a product percentage of $83,3 \%$ was obtained, so the product was very valid. From the data obtained Student Activity Sheet with Wisanggeni Puppet context on the addition and subtraction thousand numbers material appropriate to use on the quality validity level of a product designed by the researcher. Practicality of Student Activity Sheet with Wisanggeni Puppet context on the addition and subtraction thousand numbers material is viewed from the positive responses of students which are seen through the questionnaires given. Results of the assessment of student responses, it was obtained with the categories of products was 
very good and a percentage of $86.6 \%$ was included into very valid category. From these data it can be concluded that the Student Activity Sheet with Wisanggeni Puppet context on the addition and subtraction thousand numbers material has excellent criteria as teaching materials

\section{CONCLUSION}

Based on the result, can be concluded that the students Activity sheet usng Wisanggeni Puppet context developed is valid and practic. The availability of quality teaching materials may help the learning process to help the students understanding material of addition and subtraction thousand number. The writer suggests to the math teachers to use teaching materials in the form of Student Activity Sheet especially with Wisanggeni Puppet context on the addition and subtraction thousand numbers material in the fourth grade of elementary school.

\section{ACKNOWLEDGEMENT}

The researchers express their gratitude to the Indonesian Directorate General of Higher Education who has funded Student Creativity Program in 2018. Then, the researchers would like to thank to Universitas PGRI Semarang, which provides an opportunity to present and publish the results of this study.

\section{REFERENCES}

[1] Zulyadaini, "Development of Student Worksheets Based Realistic Mathematics Education (RME)", International Journal of Engineering Research and Development, vol. 19, no. 9, 2017.

[2] W. H. Cockcroft, Mathematics Counts, London: HMSO, 1986.

[3] E. Suherman, Strategi Pembelajaran Matematika Kontemporer, Bandung: UPI, 2003.

[4] A. Bishop, "Mathematics education between technology and ethnomathematics: should it be common, does it make sense? In C. Keitel et al. (eds), Mathematics (education) and common sense (proceedings of CIEAEM 47), Berlin: Freie Universitat, 1995.

[5] R. Mulyanto, "Pendekatan RME untuk Meningkatkan Pemahaman Operasi Pengurangan Bilangan Bulat Negatif pada Pembelajaran Matematika di SD N Sukaleran I Kabupaten Sumedang”, Jurnal Pendidikan Dasar, vol. 1, 2007.

[6] L. Jarlskog, " Survey of adult students with mathematical difficulties", Adults Learning Mathematics: An International Journal, vol. 11, no. 2, pp. 41-51, 2006.

[7] G. J. Roy, "Developing Prospective Teachers' Understanding of Addition and Subtraction with Whole Numbers", IUMPST: The Journal, vol 2, 2014.

[8] M. Beishuizen, "Mental strategies and materials for addition and subtraction up to 100 in Dutch second grades", Journal for Research in Mathematics Education, vol. 24, pp. 294-323, 1993.
[9] K. A. Artawan, "Penerapan Pendekatan Pendidikan Matematika Relaistik Indonesia untuk Meningkatkan Aktivitas dan Hasil Belajar Matematika Siswa Kelas V SD”, Vol.2, No. 1, 2014.

[10] C. Selter, "Addition and subtraction of three-digit numbers: German elementary children's success, methods and strategies", Educational Studies in Mathematics, vol. 47, pp. 145-173, 2002.

[11] W. M. Carroll and D. Porter, "Alternative algorithms for whole number operations", In L. J. Morrow (Ed.) Teaching and learning of algorithms in school mathematics (pp. 106-114). Reston, VA: National Council of Teachers of Mathematics, 1998.

[12] I. Thompson, "Young children's idiosyncratic algorithms for addition", Educational Studies in Mathematics, vol. 26, pp. 323-345, 1994.

[13] B. Butterworth, "The development of arithmetical abilities", Journal of Child Psychology and Psychiatry, vol. 46, no. 1, pp. 3-18, 2005.

[14] J. Halberda and L. Feigenson, "Developmental change in the acuity of the "number sense": The Approximate Number System in 3-, 4-, 5-, and 6-year-olds and adults, 2008.

[15] A. Prastowo, Panduan Kreatif Membuat Bahan Ajar Inovatif, Yogyakarta: Diva Pers, 2011.

[16] L. Sagita, "Efeketifitas Pendekatan Pembelajaran Matematika Realistik Indonesia (PMRI) untuk Peningkatan Kemampuan Matematis Siswa”, Jurnal Derivat, Vol. 1, No. 12, 2014.

[17] H. Muttaqin, R. I. I. Putri, Somakim, "Design Research on Ratio and Proportion Learning by Using Ratio Table and Graph with Oku Timur Context at the $7^{\text {th }}$ Grade", IndoMS. J.M.E., vol. 8, no. 2, pp. 211-222, 2017.

[18] F. Nursyahidah, F., R. I. I. Putri, Somakim, "Supporting First Grade Students' Understanding of Addition up to 20 Using Traditional Game", IndoMS.J.M.E., vol. 4, no. 2, pp. 212-223, 2013.

[19] F. Nursyahidah, R. I. I. Putri, Somakim, "Instructional Design of Subtraction using PMRI Approach Based on Traditional Game," in Proceedings of the $2^{\text {nd }}$ SEA-DR Conference, Palembang, 2014.

[20] F. Nursyahidah, B. A. Saputro, M. R. Rubowo, IOP Conf. Ser.: Inter. Cof. On Math., Sci, and Edu., vol. 983, 2018.

[21] B. A. Saputro, M. Prayito, F. Nursyahidah, "Media Pembelajaran Geometri Menggunakan Pendekatan Pendidikan Matematika Realistik Berbasis GeoGebra", Kreano, vol. 6, no. 1, pp. 33-38, 2015.

[22] R. C. I. Prahmana, Zulkardi. Y. Hartono, "Learning Multiplication Using Indonesian Traditional game in Third Grade", IndoMS. J.M.E., vol. 3, no. 2, pp. 115-132, 2012.

[23] A. Jaelani, R. I. I. Putri, Y. Hartono, "Students' Strategies of Measuring Time Using Traditional Gasing Game in Third Grade of Primary School", IndoMS. J.M.E., vol. 4, no. 1, pp. 29-40, 2013.

[24] Lestariningsih, R. I. I. Putri, Darmawijoyo, "The Legend of Kemaro Island for Supporting Students in Learning Average", IndoMS. J.M.E., vol. 3, no. 2, pp. 165-174, 2012.

[25] W. Widyawati, R. I. I. Putri, and Somakim, "Desain Pembelajaran Sudut Menggunakan Konteks Rumah Limas di Kelas VII”, JINOP., vol. 2, no. 2, pp. 437-448, 2016.

[26] M. K. Sari and Samsiarni, "Transformasi Pewayangan Tokoh Wisanggeni Sebuah Analisis Intertekstual Novel Wisanggeni Sang Buronan Karya Seno Gumira Ajidarma dengan Komik Lahirnya Bangbang Wisanggeni Kaya RA. Kosasi”, Jurnal Gramatika, vol 3, no. 2, pp. 131-144, 2017.

[27] A. Pambudiono and E. Suarsini, "Development of Research-Based Biotechnology Textbooks Bioremidiation of Heavy Metal Cadmium For Undergraduate Students of Biology", State University of Malang Journal of Education: Theory, Research and Development, vol. 1, pp. 1077-1085, 2016. 